\title{
Biological control of nematodes infecting eggplant in Egypt
}

\author{
Mahfouz M. M. Abd-Elgawad* (1)
}

\begin{abstract}
Background: Eggplant is of great renown in Egypt and worldwide as it is favorable and high value vegetable crop. Yet, many plant-parasitic nematodes (PPNs) can penetrate the roots of this plant and feed on it, causing heavy losses in its yield. Meloidogyne spp. (root-knot nematodes, RKNs) and Rotylenchulus reniformis rank high among these parasites in Egypt.

Main body of the abstract: This review compiles PPN ecology, biology and economic value from the pest management point of view. Applying production practices and other preventive methods against PPNs should be a priority. Accelerating and unprecedented public concern about excessive use of chemical nematicides leading to health problems, development of pest resistance, and environmental contamination, has boosted interest in developing eco-friendly biologicals as safe substitutional materials. Hence, safe biological control agents (BCAs) are reviewed herein to prove that they are quintessential to nematode control on eggplant in Egypt. Thus, BCAs should reliably operate with other agricultural inputs in integrated pest management programs against eggplant nematodes.

Short conclusion: A few paradigms are shown herein which foster BCA practical use via additive or synergistic relation with compatible inputs such as compost, chemicals, and manure. Upgrading their delivery techniques, beneficial interaction and persistence in fields with nematode-infected eggplants should be broadly tested and greatly disseminated.
\end{abstract}

Keywords: Biocontrol, Nematicides, Eggplant, Nematode management

\section{Background}

Solanum melongena L. (known as Bazingan in Egypt, aubergine in France and England, eggplant in the United States, and brinjal in India) is an economically important and popular vegetable crop in Egypt and elsewhere (Daunay 2008; Zayed et al. 2017). Its fruits range in size, shape and color depending on the varieties. The fruits may be black, purple, purple white, white, yellow or purple. Eggplant has two main groups: long (called Bride) and oval or spherical (called Romy). The fruit should be harvested as soon as it reaches maturity. Any delay in harvest time may increase the bitterness and seeds within the fruit, rendering inferior quality fruit (Zayed et al. 2017). The

*Correspondence: mahfouzian2000@yahoo.com

Plant Pathology Department, National Research Centre, Dokki, Giza 12622, Egypt plant flowers are hermaphrodite where self-pollination is made. Its fruits are eaten after cooking, boiling or grilling. The fruit is useful in the treatment of many diseases and the prevention of others (Zayed et al. 2017). Its fibers are stimulant for the intestine to help in the digestion process, expelling wastes, generating urine and cutting headache. Its crust contains vitamin $B$ and $C$ and trace amounts of calcium, iron and phosphorus in addition to flavonoids. Eggplants have plenty of fibers but low in soluble carbohydrates. As a regular food, eggplants back good blood circulation and pressure, reduce harmful cholesterol, guard the digestive tract, and assist to control diabetes (Zayed et al. 2017). According to the FAO in 2012 , 90\% of the eggplant yield is produced by five countries: China, India, Iran, Egypt and Turkey (Ismael et al. 2017). Eggplant is a warm-season vegetable but can grow in Egypt at different seasons; 35-60-day-old seedlings 
are transplanted early (in March) or late (April and May) in summer season, July and August (fall season), and November and December (winter season, under plastic tunnels). Harvest often occurs 65 to 80 days after transplanting, depending on the variety and temperature. When starting from seed, about 100-120 days are required to reach maturity. Eggplant is actually a perennial, but most people treat it as annual, because it is not frost tolerant. So, in the warm regions like Egypt, plants can keep up production but plants are sharply pruned after the harvest and kept alive till next March when they are fertilized for second season production (Zayed et al. 2017).

However, eggplants are generally so susceptible to some biotic stresses. Among such stresses, a variety of the most dominant and globally spread pests is the plant-parasitic nematodes (PPNs) which can reduce yield significantly. Detailed effect of soil fertility and pesticides on nematode activity, other microbiota, and its subsequent effect on crop yield was reported elsewhere (Abd-Elgawad and Mohamed 2006; Rahman et al. 2020). Abd-Elgawad (2014) assessed losses of eggplant yield due to damage by PPNs in Egypt as $20 \%$ of total annual yield which may translate into $298,410.5$ metric tons of yield loss. However, PPN populations may damage eggplant yields in various settings differently according to the pathogenicity of PPN species, and the nematode density as well as the relevant interacting factors which impact the cultivated eggplant. Thus, accurate sampling approaches are required for precise and close quantification of these pests (Abd-Elgawad 2016a, b). A few PPN species have also proved to predispose eggplants to infection by fungal or bacterial pathogens or to transmit virus diseases, which usually aggravate losses of eggplant yield (Noling 2019).

Ibrahim (2006) reported the next PPN genera (and their related species) associated with eggplants as economically significant pests: Helicotylenchus (H. dihystera, $H$. cavenessi, $H$. pseudorobustus), Meloidogyne (M. incognita, M. javanica, $M$. arenaria), Pratylenchus ( $P$. brachyurus, $P$. jordanensis, $P$. penetrans, $P$. thornei), Rotylenchulus (R. reniformis, R. parvus) and Xiphinema americanum. Generally, the life cycle of PPNs goes through bisexual adults, eggs, and four larval stages. Usually the second sage larvae or juveniles hatch to search and feed on plant roots or in some PPN species on foliar tissues. According to their feeding site and habitat, PPNs may be categorized as semi-endoparasites (e.g., reniform nematodes; Rotylenchulus spp.), migratory endoparasites (e.g., lesion nematodes; Pratylenchus spp.), sedentary endoparasites [e.g., root-knot nematodes (RKNs)]; Meloidogyne spp.), and ectoparasitic nematodes (e.g., spiral; Helicotylenchus). An average of about 50-100 eggs are laid by a female, but serious genera as Meloidogyne, may lay up to 2000 eggs. The life cycle often lasts 4 to 8 weeks; usually relatively high temperature hasten the cycle duration where optimal soil temperature $21.1-26.7^{\circ} \mathrm{C}$ (Noling 2019). Next are the most significant and prevalent PPN species of eggplant grown in Egypt:

\section{Main text \\ PPNs of eggplant in Egypt \\ Root-knot nematodes (Meloidogyne spp.)}

Nematode spread and distribution patterns These endoparasites have obligate feeding habit on crop roots. The nematode group is characterized by its broad host range that shackles the accessibility of resistant/immune cultivars in crop sequences. Such a wide range covers a wide variety of plants; not only woody and herbaceous plants, but generally monocotyledonous and dicotyledonous plants. Eggplants grafted on RKN-resistant rootstocks are sometimes used. Hence, nematode-resistant sources are still necessary for breeding programs given the fact that some related Solanum species such as S. torvum has high resistance level to Meloidogyne spp. (Daunay 2008; Öçal and Devran 2019; Gisbert et al. 2011). Also, eggplants were genetically engineered via the tomato $\mathrm{Mi}-1.2$ gene and thus acquired resistance to $M$. javanica (Goggin et al. 2006). Papolu et al. (2016) suggested that cystatins can help in enhancing the eggplant resistance within a strategy that could eventually increase crop yield. Although this nematode group includes more than 90 species, only four species (M. incognita, M. hapla, M. javanica, and M. arenaria) are globally main pests; other seven species are serious from a regional or local scope (Moens et al. 2009).

Meloidogyne spp. perform a major obstacle especially for horizontal expansion of crop production including eggplant cultivation in Egypt, because these species thrive in light and sandy soils. Hence, reclaimed deserts present an optimum status for their establishment and multiplication (Abd-Elgawad 2020a). Consequently, RKNs are the most widespread and significant PPN genus damaging many plant species in Egypt. This genus recorded $62.5 \%$ frequency of occurrence (Ibrahim et al. 2010; Abd-Elgawad 2019a). Its species were detected in as many as $96.26 \%$ of the examined fields in such lands (Bakr et al. 2011). The fields are perceivably planted to field and horticultural crops, e.g., eggplant. This study covered various categories of reclaimed but light soils located at El-Beheira (El-Tahrir), Minufiya (El-Sadat), and Sharkiya (El-Salhiya) governorates. Also, RKNs were more dominant in agricultural soil of Sahl El-Teina, Beer El-Abd, and El-Sheikh Zowaiid with the percentage frequency of $27.6,48.1$, and $33.3 \%$, respectively (Korayem et al. 2014). Clearly, densities of RKN population differed from one field to another as the nematodes were 
subjected to various control methods and production practices, in addition to biological and physical factors.

Frequently, PPNs display clumped distribution in Egypt (Abd-Elgawad 1992; Abd-Elgawad and Hasabo 1995; Abd-Elgawad et al. 2016, a, b, c) and worldwide (Duncan and Phillips 2009; Abd-Elgawad and Askary 2015) in general. Therefore, patches of RKN infections possibly in scattered areas/sites of the field can be observed where eggplant seedlings fail to grow normally. So, weakening symptoms on stunted plants often occur in spots of noneven plant growth, i.e., non-uniform damage of eggplants over the whole planted area (Fig. 1). Nematodes spreading in these spots or patchy areas should be adequately managed at the season-start. If not, they may expand and develop in size of the infested field sites to cover almost all eggplant-cultivated fields.

RKN Pathology and losses Like other PPNs, the common symptoms of RKN injury on eggplant are stunted plants and decrease in their growth parameters which ultimately lead to considerable loss. The intensity of RKN disease symptoms is positively correlated with initial density of RKN populations and their reproduction capacity which depend on the biological and environmental factors during the plant growing season. Eggplants infected by RKNs are often more deteriorated by noxious weeds than plants without RKN infection. This is definitely because the plants cannot often stand for weed competition or any other stresses. Factually, plant weakness of infected plants is mostly due to insufficient mineral nutrition or water supply to the tops. Hence, the infected eggplants exhibit symptoms that are characteristic of nutrient deficiency such as leaf yellowing/chlorosis, slow response to adequate soil moisture conditions, and premature wilting. Unmistakably, RKNs infection and consequent feeding on plant roots will result in knot-like swellings known as nematode galls on the eggplant roots (Fig. 2) due to formation of giant cells inside the tissues of plant roots. When plants are harshly attacked and infected by RKNs, the intact root system is diminished to a confined volume of remarkably RKN-galled roots where the vascular system of the eggplant roots is greatly disorganized. Factually, eggplant growth reduction and loss in yield are correlated with nematode population density, the magnitude of host suitability, and the implemented control measures (e.g., Abd-Elgawad et al. 2019), as well as biological and ecological conditions. Eggplant roots may bear different numbers and sizes of RKN galls with different shapes and locations on the root system (Fig. 2).

Action thresholds necessitate RKN control for infected eggplants if a single nematode was detected per $100 \mathrm{~cm}^{3}$ of eggplant-cultivated soil in Egypt and other countries (Abd-Elgawad and Askary 2015). Therefore, promising research results especially of RKN biocontrol on eggplant which will be presented herein should further be practiced on wider scale in Egypt.

\section{Lesion nematodes (Pratylenchus spp.)}

Pathogenicity In fact, the losses and prevailing distribution of RKNs often hide the role and losses of other PPN genera such as lesion nematodes, Pratylenchus, and reniform nematode, Rotylenchulus on eggplant. Clearly, Pratylenchus spp. have a broad host range feeding on most cultivated Various weed species also may back the nematode reproduction as suitable hosts. Admittedly, different species of Pratylenchus are associated with various crops, grasses, and weeds in Egyptian soils (Abd-Elgawad 2019a). Hence, it is quite possible to cultivate eggplant in the above-mentioned soils reported by Ibrahim (2006) to be infested with one or more of Pratylenchus spp. However, little information is available on the exact eggplant yield damage/loss by a definite Pratylenchus sp. in Egypt. Moreover, lesion nematodes can also predispose plants to invasion by some genera of soil borne pathogens in addition to their direct damage in parasitizing eggplants. For example, in steam-sterilized soil inoculated with Verticillium alboatrum and Pratylenchus penetrans, McKeen and Mountain (1960) demonstrated a synergistic relationship between $V$. alboatrum and $P$. penetrans. At low and intermediate levels of Verticillium inoculum, the nematode increased wilt may be a function of the number of nematodes present. Except at the high inoculum levels of Verticillium, significantly larger numbers of $P$. penetrans occurred in eggplant roots in the presence than in the absence of the fungus. On the other hand, Mizukubo (1995) tested the reproduction of three populations of Pratylenchus coffeae in Japan and proved the presence of physiological races among them on eggplant. Also, Di Vito et al. (2002) examined six population of Pratylenchus spp. from the Mediterranean region and found that eggplant was good host for $P$. neglectus but $P$. pinguicaudatus reproduced better on faba bean, lentil and pea than on eggplant. Machado and Inomoto (2001) used the nematode-reproduction factor or $\mathrm{Rf}$ [=the nematode-final population (Pf) divided by the nematode-initial population $(\mathrm{Pi})$; or $\mathrm{Rf}=\mathrm{Pf} / \mathrm{Pi}$ ] to examine host suitability of eggplants to Pratylenchus brachyurus. They reported that intermediate nematode populations occurred at 65 days after $P$. brachyurus inoculation $(\mathrm{Pf} / \mathrm{Pi}=2.78)$, but in Khan's (1992) study of the same crop, a strong population increase $(\mathrm{Pf} / \mathrm{Pi}=31.4$ at 75 days after inoculation) was demonstrated.

Control measures Pratylenchus spp. should have a comprehensive control measures within integrated pest management (IPM) approach. A basic control measure in this 
approach is to use nursery stock free from the nematodes. Also, rotating resistant plant cultivars/species such as pearl millet with susceptible eggplants could be utilized successfully in Egypt. Like other solanaceous crops such as tomato and pepper, chemical nematicides can effectively control PPNs on eggplant but their related health hazards, development of pest resistance, and environmental pollution should be avoided. Also, raising awareness of growers via guiding them to sound production exercises such as destruction of weeds and infected-plant residues in eggplant fields can upgrade nematode control (Abd-Elgawad 2019a, b).

\section{Reniform nematode (Rotylenchulus reniformis)}

Lone et al. (2014) stressed that Rotylenchulus with 10 species are prevalent and significant group of PPNs globally but often detected in tropical and subtropical climate. Among its species, $R$. reniformis with at least 314 plant host species is the most prominent and economically appreciated one (Robinson et al. 1997). Reniform nematodes rob nutrients of infected plants and reduce the quantity and quality of the eggplant fruits. Symptoms are primary expressed as minimized root systems, nutrient deficiency, and stunting of the infected plants. Reduction in plant longevity negatively affects harvest duration. Economically appreciated management of reniform nematodes in view of their worldwide distribution and broad host range especially for $R$. reniformis has always been a dire need for growers globally (Lone et al. 2014).

The lifecycle of reniform nematode was recently reported (Abd-Elgawad 2020a). Its time span is frequently less than three weeks in warm regions. The nematode can survive for more than two years without its host under stressed condition, i.e., in dry soil. In such a case, $R$. reniformis can live in a dormant state stimulated by drought and the nematode is almost dehydrated with diminished metabolic activity; a condition called anhydrobiosis that helps $R$. reniformis to live without water for long time (Wang 2019). On infecting plant roots, the nematode female establishes a feeding site comprising syncytial cells.

Most manifestations and disease signs resulting from PPN infection are generally identical to those of lack in nutrients and eggplant irrigation. As $R$. reniformis feeds on the eggplant roots, the growth of the whole plant is decreased. Additional infection by other soil borne pathogens after $R$. reniformis establishment on eggplant roots can worsen plant status. Both $R$. reniformis and RKN have sexual dimorphism.

\section{Other plant-parasitic nematodes}

Additional PPNs have obviously been less recognized regarding their economic significance (Ibrahim 2006) and are entitled to more investigations in Egypt. These include the nematodes in the genera Xiphinema, Longidorus, Hoplolaimus, Paratrichodorus, Trichodorus, and Tylenchorhynchus. They are frequently associated with eggplant roots in Egypt but in low frequency of occurrence and population densities. Therefore, further investigations on any of them may reveal whether they demonstrate economic importance and determine their damage on eggplants in Egypt.

Also, the significance of other nematodes on eggplants has been reported from other countries, e.g., Belonolaimus longicaudatus in Florida, USA (Noling 2019). Likewise, action thresholds are suggested for any detection of sting or stubby-root nematodes; usually in sample size of $100 \mathrm{~cm}^{3}$ soil of eggplant-planted field. The corresponding thresholds are 10, 40, and 80 nematodes for awl, stunt, and lesion nematodes, respectively (Abd-Elgawad and Askary 2015). Yet, further PPN species and additional relevant factors may alter the threshold from one location/season to another (Wang 2019).

\section{Expertise for biocontrol of PPNs on eggplant Application of microorganisms}

Chubachi et al. (2003) found that Streptomyces sp. strain NA-369 can control $M$. incognita infecting eggplant. Significant reductions in the gall index of eggplants and advantageous changes in nematode population density and growth parameters of eggplants resulted from the strain NA-369 addition to amend the soil relative to the check area. Also, Serratia marcescens, ground ascaris (Ascaris lumbricoides) cuticle, two entomopathogenic nematode (EPN) species (Heterorhabditis bacteriophora strain EGG and Steinernema carpocapsae strain All, and garlic extract added to the soil singly, were tested to control M. incognita on eggplant in the glass-house (AbdElgawad and Mohamed 2006). These additions were also compared with the nematicide oxamyl. All the treatments fostered various parameters of plant growth but differently. El-Sherif et al. (2007) tested sesame-oil-cake, horse manure or Bacillus thuringiensis singly and/or incorporated with oxamyl on $M$. incognita infecting eggplant. All tested materials were obviously advantageous in terms of fostering plant growth and suppressing nematode population; $B$. thuringiensis as single addition or incorporated with oxamyl showed the best plant growth parameters. Incorporating horse manure with oxamyl seemed to be the best application in controlling $M$. incognita development and improving plant growth parameters.

\section{Further integrated application}

In a glasshouse experiment, Usman and Siddiqui (2012) tested T. harzianum and Purpureocillium lilacinus at the same time along with $M$. incognita on eggplant. 
They found that these biocontrol agents were effective in suppressing $M$. incognita and could be used as safe agents for sustainable environment. Abolusoro et al. (2013) reported that organic manure (poultry, cow dung, domestic waste) and inorganic fertilizer (NPK 15:15:15) were effective in suppressing $M$. incognita soil and root populations, reducing gall index of the treated eggplants compared with the control in a greenhouse Mokbel and Alharbi (2014) found that Pseudomonas fluorescens, B. thuringiensis, Bacillus subtilis, and S. marcescens each alone or in a combination resulted in 50.5-90.3\% restrained $M$. javanica egg-hatch and $\mathrm{J}_{2}$ activity and caused 56.5-86.8\% decrease in egg-masses/eggplant root system, root galls,, and $50.9-73.7 \%$ rise in the shoot and root dry weights of eggplant. Also, Arthrobotrys conoides, Purpureocillium lilacinus, A. oligospora, and Saccharomyces cerevisiae induced considerable reductions (69.5$89.5 \%)$ in galls and egg-masses/root system, and led to 53.7-60.9\% enhancement in shoot and root dry weights of eggplant. The potency of $P$. lilacinus in colonizing $M$. javanica egg masses and eggs formed on eggplant roots ranged from 45.2 to $99.2 \%$, relative to the untreated control. Lone et al. (2014) found that the simultaneous inoculation of $R$. reniformis with different inoculum levels of Steinernema sp. considerably decreased the injury resulted from $R$. reniformis infection. The best results were attributed to with the dose of 5000 infective juveniles of Steinernema sp./500 g soil. Abdellatif et al. (2016) tested the efficacy of green silver nanoparticles (GSN) of $\mathrm{AgNO}_{3}$ dissolved in two separate algal (Ulva lactuca or Turbinaria turbinata) extract solution on reproduction parameters of $M$. javanica on eggplant. All treatments improved eggplants growth parameters but $U$. lactuca was more effective in reducing second-stage juveniles $\left(\mathrm{J}_{2}\right)$ of M. javanica (69\%) population in soil. In pot experiment, Khushbu et al. (2016) found that soil application with $T$. harzianum at $3 \mathrm{~g} / \mathrm{kg}$ soil was better than T. viride and $P$. Fluorescens at $3 \mathrm{~g} / \mathrm{kg}$ soil in enhancing plant growth of brinjal and managing $M$. incognita. However, the chemical check carbofuran 3G at $2 \mathrm{~kg}$ a.i. per ha gave the best results. Gad and Sergany (2017) studied the effect of dried leaf powders of cabbage, sorrel, spinach, rocket and tomato compared to oxamyl on M. incognita infecting eggplant under greenhouse conditions. All treatments showed remarkable increase in plant growth parameters and reduced nematode criteria. Ismael et al. (2017) found that the Rf of $M$. incognita were 0 and 0.50 when plant extract mixture product (Nemakey) and Humic acid $15 \%$ were applied on eggplants, respectively. Humic acid had the highest no. of fruits /plant, while Nemakey had significant effects on increasing fruit weight (g), and yield (kg/plant). Deimi and Karami (2017) noted that drenching application of compost teas derived from rice straw gave more $(P<0.05)$ fresh weight of eggplant infected with $M$. javanica or $R$. reniformis than those derived from rice hull, tomato, potato, citrus, guava and city waste compost. Zeerak et al. (2017) found that as endospore level of Pasteuria isolates PP-J and PP-3/ $\mathrm{J}_{2}$ increased, the nematode development stages decreased. The two isolates of Pasteuria penetrans were remarkably effective though PP-3 was superior to the other one. Osman et al. (2018) used either single or combined treatments of Trichoderma harzianum filtrate, inorganic fertilizer, chicken manure, Bacillus thuringiensis, NPK, and Oxamyl for field control of both root rot disease and $M$. incognita infecting eggplant in Egypt. All such treatments had variable activities against the root rot disease incidence and $M$. incognita though enhanced the crop yield. The chicken manure had the best results but combined treatments were generally better than single treatments in increasing the eggplant yield. Abd-El-Khair et al. (2018) used T. harazianum, T. virens and the oil cakes of olive and castor bean alone or in combination for controlling Fusarium solani and M. incognita on eggplants in pots experiment. Either Trichoderma with any of oil cakes decreased root rot disease incidence, reduced nematode parameters (viz. $\mathrm{J}_{2}$ in soil \& roots and the numbers of galls \& egg-masses), and enhanced the growth parameters of eggplants compared to the control in Egypt. Noweer and Elkelany (2019) used Dactylaria brochopaga as nematode-trapping fungus and Verticilium chlamydosporium mixed with molasses, yeast, and vermiculate to considerably suppress $M$. incognita infecting eggplant under field condition in Egypt. The data revealed that the weights of eggplant yield per plant were significantly enhanced due to $D$. brochopaga treatments relative to the check.

\section{General approaches for management of PPNs infecting eggplant in Egypt \\ Strategies}

Crop rotation with other resistant/immune plant species/ cultivars should be practiced though eggplant-resistant cultivars are still desperately needed (Papolu et al. 2016 and Öçal and Devran 2019). More importantly, phytosanitary measures should be continuously practiced in eggplant fields to avoid their infestations by the nematodes especially in newly reclaimed areas with light soils where RKNs can readily thrive. In such areas, caution should be exercised, because the nematodes can attack cultivated area in the newly reclaimed land via infected or unhealthy seedlings, contaminated soil, organic fertilizers, machinery, plant materials, and irrigation which may contain the nematodes. For current susceptible eggplants, management via various chemical nematicides is so common control practice in Egypt. The Egyptian 
Ministry of Agriculture recommended such nematicides as oxamyl (Oxanem 24\% SL, Vydate 10\% GR and 24\% SL), Fenatode 10\% GR), cadusafos (Rugby $10 \mathrm{G}$ ), fenamiphos (Dento 40\% EC, ethoprophos (Nemacap 20\% EC), and fosthiazate (Nemathorin 10\% GR) to manage RKNs on solanaceous crops (Anonymous 2017). Such chemicals can give some nematode control and increase eggplant yields. Their possible combination and mode of application (granular, drenching etc.) has various effects on soil fauna and flora (Abd-Elgawad 2008; Meena et al 2020). Nonetheless, due to risks of expected health probability and ecological pollution by these chemicals, biocontrol methods should be advanced as an important device in IPM programs of eggplant noxious pathogens and pests.

\section{Application of bioagents}

Considering the various views of gaining in managing PPNs on eggplant using ecofriendly methods, functional sampling to enhance isolation of BCAs should be practiced (Abd-Elgawad 2020b). Moreover, a few locally adapted bio-nematicides have been commercialized in Egypt (Table 1). Labels attached to the bio-nematicides may present the necessary instructions for their adequate storage and practical use. So, they should be followed. The effectiveness of such bionematicides on different nematodes is generally known to reduce their population levels to non-damaging ones. Clearly, production practices of eggplants should enhance both application of such local products and efficacy to control PPNs (Abd-Elgawad and Askary 2020). Identification of the major relevant bio-agents, their mass production, release method, mode of assessing effectiveness, interaction with other agricultural inputs, and effect in the crop's ecosystem were reviewed (Abd-Elgawad 2016a, c; Abd-Elgawad 2017a; Abd-Elgawad and Askary 2018). Such information is especially timely since most of these products are easily obtained with relatively cheap prices compared to chemical nematicides in Egypt (Table 1). On the other hand,

Table 1 Key commercial bionematicides and synthetic nematicides, their practical rates, and prices in Egypt*

\begin{tabular}{|c|c|c|c|}
\hline Active ingredient & Product name & $\begin{array}{l}\text { Application rate } \\
\left.\text { (product/Feddan }^{-1}\right)^{+}\end{array}$ & Price per Feddan \\
\hline $\begin{array}{l}\text { Abamectin produced during the fermentation process of Streptomyces avermitilis } \\
\text { (soluble concentrate at } 20 \mathrm{~g} / \mathrm{l})\end{array}$ & Tervigo $2 \%$ SC & $2.5 \mathrm{~L} /$ Feddan & L.E. 2000 \\
\hline $\begin{array}{l}\text { Bacillus circulans, Serratia sp., B. thuringiensis, Pseudomonas sp., and Azotobacter sp. at } \\
10^{9} \mathrm{CFU} / \mathrm{ml}\end{array}$ & Micronema & 30 L / Feddan (thrice) / year & L.E. 600 \\
\hline Purpureocillium lilacinus ( $10^{8}$ units/ml) & Bio-Nematon & $2 \mathrm{~L} /$ Feddan/ year & L.E. 500 \\
\hline $10^{9}$ Serratia marcescens cells /ml water) & Nemaless & $10 \mathrm{~L} /$ Feddan (thrice)/ year & L.E. 600 \\
\hline Cadusafos (O-ethyl S,S-bis (1-methylpropyl) phosphorodithioate) & Rugby $10 \mathrm{G}$ & $24 \mathrm{~kg} /$ Feddan & L.E. 6480 \\
\hline $\begin{array}{l}\text { Oxamyl (methyl 2-(dimethylamino)-N-(methylcarbamoyloxy)-2 oxoethanimidothio- } \\
\text { ate) }\end{array}$ & Vydate $24 \%$ SL & $4 \mathrm{~L} /$ Feddan (twice) / year & L.E. 2800 \\
\hline
\end{tabular}

* The host range assumed by the producers on the product labels is not necessarily confirmed in neutral tests (Wilson and Jackson 2013)

+ The rates are evenly applied to the soil (except oxamyl for foliar application too). In some cases, these rates may be incorporated into potting mix, field soil, or applied in greenhouses for which other doses are used (Abd-Elgawad 2020a)

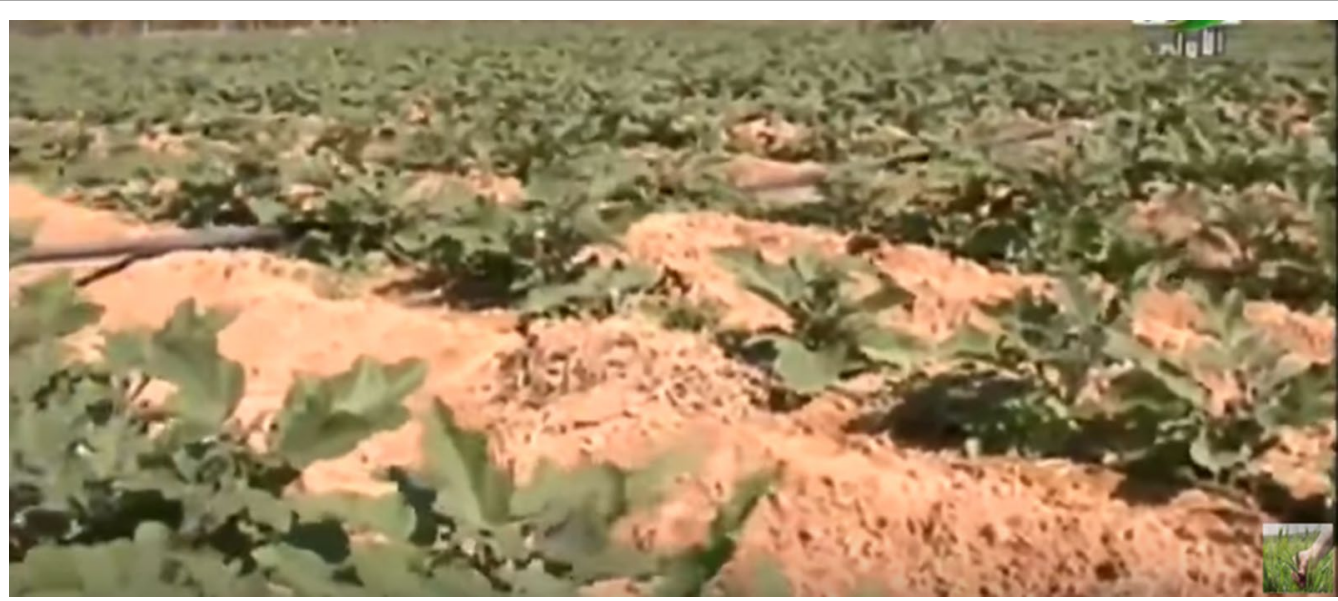

Fig. 1 An Eggplant field showing patchy area due to root-knot nematode (Meloidogyne spp.) infestation 


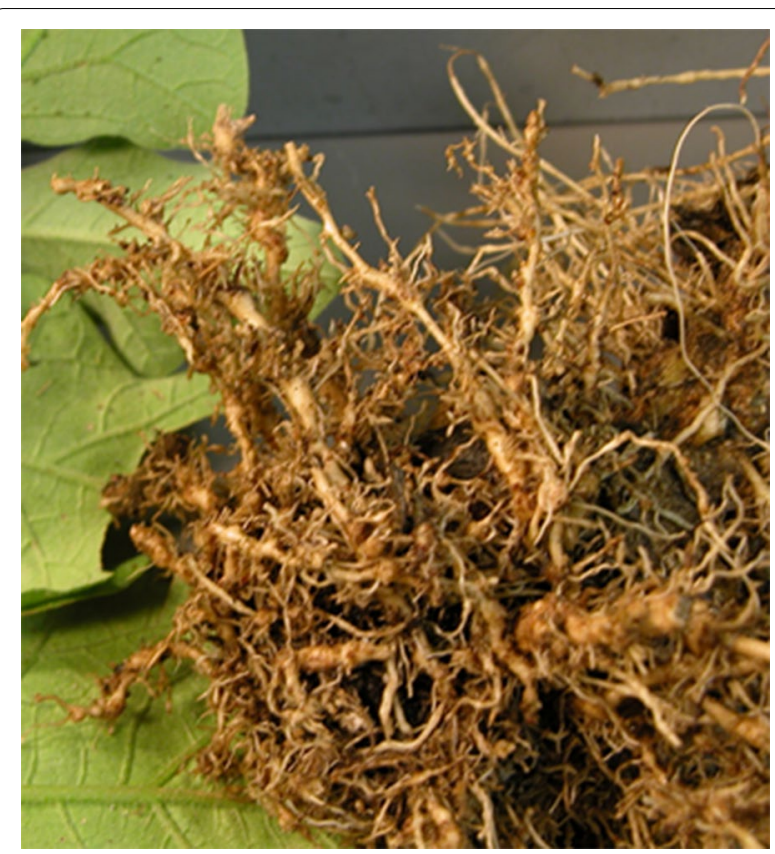

Fig. 2 Root-knot nematodes (Meloidogyne spp.) inducing different gall sizes of eggplant roots

applying the entomopathogenic nematodes and their symbiotic bacteria or their byproducts to control different groups of pests in IPM programs has been suggested (Abd-Elgawad 2017a, b). For examples, these nematodes could effectively control both $M$. incognita on eggplant (Abd-Elgawad and Mohamed 2006) and Tylenchulus semipenetrans on Mandarin (Hammam et al. 2016) in Egypt. Additionally, agricultural extension should disseminate the best BCA use (Dougoud et al. 2018) via their interaction with the above-mentioned compatible inputs such as chemicals and organic manure. Such disseminations should also include accurate evaluation of efficient biocontrol programs (Abd-Elgawad 2016c), synergistic combinations against plant-parasitic nematodes (Abd-Elgawad and Askary 2018), developing techniques of BCAs against PPNs (Abd-Elgawad and Askary 2020), and registration of new BCAs against PPNs (Wilson and Jackson 2013; Hammam et al. 2016). Therefore, the expertise of research institutions in Egypt and elsewhere were brought together in the above-mentioned section to offer a realistic biocontrol of PPNs on eggplant. It provides a first approximation of the combined factors that could possibly contribute in such IPM programs.

\section{Conclusions}

Eggplant is a popular food crop in Egypt but many PPNs particularly RKNs and Rotylenchulus reniformis can significantly reduce its crop yield. Chemical nematicides are effectively used to combat the nematodes but their irrational use may contaminate the environment and issue health problems. The effects of nematicides were reported and pesticides' residue studies have been informative (Abd-Elgawad 2008; Meena et al. 2020). Therefore, good agricultural practices and other preventive methods should be utilized in addition to BCAs as safe alternatives to control the nematodes on eggplant in Egypt. Numerous examples of such BCAs proved a promising tool in this direction. However, the complicated interactions among physical and biotic factors closely associated with such BCAs to optimize their benefits via safe and wise usage and upgraded technology should be well understood. Thus, accurate estimate of efficient biocontrol programs, synergistic or additive combinations including BCAs against PPNs, and effective techniques of harnessing novel and currently available BCAs against PPNs on eggplants should be carefully examined before utilization.

\section{Abbreviations}

PPN: Plant-parasitic nematode; BCAs: Biological control agents; IPM: Integrated pest management; Pi: Nematode-initial population; Pf: Nematode-final population; Rf: Nematode-reproduction factor.

\section{Acknowledgements}

This study was supported in part by the NRC In-house Project No. 12050105 entitled "Pesticide alternatives against soil-borne pathogens and pests attacking economically important solanaceous crops."The author is grateful to Dr. MMM Bondok for providing the two plates. Facilities offered by The National Research Centre are appreciated.

\section{Authors' contributions}

The author has developed and implemented this review article and written it.

\section{Funding}

Financial support made by the National Research Centre, Egypt, is gratefully acknowledged.

\section{Availability of data and materials}

The datasets used and/or analyzed during the current study are available from the corresponding author on reasonable request.

\section{Ethics approval and consent to participate}

Not applicable.

\section{Consent for publication}

Not applicable.

\section{Competing interests}

The author declares that he has no competing interests.

Received: 21 March 2020 Accepted: 4 December 2020

Published online: 06 January 2021

\section{References}

Abd-El-Khair H, El-Nagdi WMA, Hammam MMA (2018) Effect of olive and castor bean oil cakes singly or combined with Trichoderma spp. on Fusarium solani and Meloidogyne incognita infecting eggplant. Middle East J Appl Sci 8(2):465-473 
Abd-Elgawad MM (1992) Spatial distribution of the phytonematode community in Egyptian citrus groves. Revue Nematol 14:367-373

Abd-Elgawad MMM (2008) The current status of phytonematode management in Egypt with special reference to applicable nematicides. Egypt J Agronematol 6:33-46

Abd-Elgawad MMM (2014) Yield losses by phytonematodes: challenges and opportunities with special reference to Egypt. Egyptian J Agronematol 13(1):75-94

Abd-Elgawad MMM (2016a) Biological control agents of plant-parasitic nematodes: a review. Egypt J Biol Pest Cont 26(2):423-429

Abd-Elgawad MMM (2016b) Use of Taylor's power law parameters in nematode sampling. Int J PharmTech Res 9(12):999-1004

Abd-Elgawad MMM (2016c) Comments on the use of biocontrol agents against plant-parasitic nematodes. Int J PharmTech Res 9(12):352-359

Abd-Elgawad MMM (2019b) Towards optimization of entomopathogenic nematodes for more service in the biological control of insect pests. Egypt J Biol Pest Cont 29:77. https://doi.org/10.1186/s41938-019-0181-1

Abd-Elgawad MMM (2019a) Plant-parasitic nematodes of Strawberry in Egypt: a review. Bull NRC 43:7. https://doi.org/10.1186/s42269-019-0049-2

Abd-Elgawad MMM (2020) Can rational sampling maximize isolation and fix distribution measure of entomopathogenic nematodes? Nematology. https://doi.org/10.1163/15685411-00003350

Abd-Elgawad MMM (2017a) Status of entomopathogenic nematodes in integrated pest management strategies in Egypt. In: Abd-Elgawad MMM, Askary TH, Coupland J (eds) Biocontrol agents: entomopathogenic and slug parasitic nematodes. CAB International, Wallingford, pp 473-501

Abd-Elgawad MMM (2017b) Toxic secretions of Photorhabdus and their efficacy against crop insect pests. In: Abd-Elgawad MMM, Askary TH, Coupland J (eds) Biocontrol agents: entomopathogenic and slug parasitic nematodes. CAB International, Wallingford, pp 231-260

Abd-Elgawad MMM, Askary TH (2018) Fungal and bacterial nematicides in integrated nematode management strategies. Egypt J Biol Pest Cont 28:74. https://doi.org/10.1186/s41938-018-0080-x

Abd-Elgawad MMM, Askary TH (2020) Factors affecting success of biological agents used in controlling plant-parasitic nematodes. Egypt J Biol Pest Cont 30:17. https://doi.org/10.1186/s41938-020-00215-2

Abd-Elgawad MMM, Askary TH (2015) Impact of phytonematodes on agriculture economy. In: Askary TH, Martinelli PRP (eds) Biocontrol agents of phytonematodes. CAB International, Wallingford, pp 3-49

Abd-Elgawad MMM, Elshahawy IE, Abd-El-Kareem F (2019) Efficacy of soil solarization on black root rot disease and speculation on its leverage on nematodes and weeds of strawberry in Egypt. Bull NRC 43:175. https:// doi.org/10.1186/s42269-019-0236-1

Abd-Elgawad MMM, Hasabo SA (1995) Spatial distribution of the phytonematode community in Egyptian berseem clover fields. Fundam Appl Nematol 18:329-334

Abd-Elgawad MMM, Koura FFH, Montasser SA, Hammam MMA (2016) Distribution and losses of Tylenchulus semipenetrans in citrus orchards on reclaimed land in Egypt. Nematology 18:1141-1150

Abd-Elgawad MMM, Mohamed MMM (2006) Efficacy of selected biocontrol agents on Meloidogyne incognita on eggplant. Nematol Medit 34:105-109

Abd-Elgawad MMM (2020a) Optimizing biological control agents for controlling nematodes of tomato in Egypt. Egypt J Biol Pest Cont 30:Submitted

Abdekkatif KF, Hamouda RA, El-Ansary MSM (2016) Green nanoparticles engineering on root-knot nematode infecting eggplants and their effect on plant DNA modification. Iran J Biotech. https://doi.org/10.15171/ijb.1309

Abolusoro SA, Abe MO, Abolussoro PF, Izuogu NB (2013) Control of nematode disease of eggplant (Solanum aethiopicum L.) using manure. Agric Conspectus Sci 78(4):1-4

Anonymous (2017) Adopted recommendations to combat agricultural pests (in Arabic). Dekerness, Dakahlia, Egypt, Agricultural Pesticide Committee, Ministry of Agriculture, Media Support Center Press.

Bakr RA, Mahdy ME, Mousa EM (2011) A survey of root-knot and citrus nematodes in some new reclaimed lands in Egypt. Pak J Nematol 29(2):165-170

Chubachi K, Fukuda S, Matsumura S, Yanagisawa T, Itagawa H, Shimizu T, Nakagawa A (2003) Suppression of root-knot nematode disease in eggplants by antinematodal Streptomyces NA-369 in artificially infested soil. Biocontrol Sci 8(2):93-96
Daunay MC (2008) Eggplant. In: Prohens J, Nuez F (eds) Handbook of plant breeding: vegetables II. Springer, New York, pp 163-220

Deimi AM, Karami A (2017) Effect of some botanicals compost for reducing Meloidogyne javanica and Rotylenchulus reniformis and altering chemical constituents in eggplant in Kerman. Iran Int J Adv Res Biol Sci 4(8):85-93

Dougoud J, Cock MJW, Edgington S, Kuhlmann U (2018) A baseline study using Plantwise information to assess the contribution of extension services to the uptake of augmentative biological control in selected low- to lower-middle- income countries. Biocontrol 63(1):117-132. https://doi. org/10.1007/s10526-017-9823-y

Duncan LW, Phillips MS (2009) Sampling root-knot nematodes. In: Perry RN, Moens M, Starr JL (eds) Root-knot nematodes. CAB International, St. Albans, pp 275-300

El-Sherif AG, Refaei AR, El-Nagar ME, Salem HMM (2007) Integrated management of Meloidogyne incognita infecting eggplant by certain organic amendments, Bacillus thuringiensis and Oxamyl with reference to N P K and total chlorophyll status. PI Pathol J 6:147-152

Gad SB, Sergany MI (2017) Influence of five plant dried leaf powders on eggplant plants infected with Meloidogyne incognita under greenhouse conditions. Egypt J Agronematol 16(1):1-10

Gisbert C, Prohens J, Raigón MD, Stommel JR, Nuez F (2011) Eggplant relatives as sources of variation for developing new rootstocks: Effects of grafting on eggplant yield and fruit apparent quality and composition. Scientia Hort 128:14-22

Goggin FL, Jia LL, Shah G, Hebert S, Williamson VM, Ullman DE (2006) Heterologous expression of the Mi-1.2 gene from tomato confers resistance against nematodes but not aphids in eggplant. Molecul PI-Microbe Interact 19(4):383-388

Hammam MMA, El-Nagdi WMA, Abd-Elgawad MMM (2016) Biological and chemical control of the citrus nematode, Tylenchulus semipenetrans (Cobb, 1913) on Mandarin in Egypt. Egypt J Biol Pest Cont 26(2):345-349

Ibrahim IKA (2006) Diseases and pests of vegetable crops and control methods. Monshaat Al-Maarf Publisher, Alexandria

Ibrahim IKA, Mokbel AA, Handoo ZA (2010) Current status of phytoparasitic nematodes and their host plants in Egypt. Nematropica 40:239-262

Ismael JHS, Sulaiman SM, Muhidden A, Faraj SM, Abdul-Khaliq H (2017) Control of root-knot nematode of eggplant and its effect on plant growth. Int J Forest Horticult 3(2):28-34

Khan FA (1992) Multiplication rates of Pratylenchus brachyurus in some vegetable crops in northern Nigeria. Crop Protect 11:127-130

Khushbu S, Sharma HK, Bhati SS, Nama CP, Pushpa P (2016) Effect of bioagents as soil application against root-knot nematode, Meloidogyne incognita infecting brinjal. Int J Agric Sci 8(33):1687-1689

Korayem AM, Youssef MMA, Mohamed MMM, Lashein AMS (2014) A survey of plant parasitic nematodes associated with different plants in North Sinai. Mid East J Agric Res 3(3):522-529

Lone JA, Parveenb G, Khan TA (2014) Comparison of concomitant and sequential inoculation of Steinernema sp. in the management of reniform (Rotylenchulus reniformis) nematode infecting eggplant. e-J Sci \& Tech 2(9):97-111

Machado ACZ, Inomoto MM (2001) Host status of eighteen vegetable crops for Pratylenchus brachyurus. Nematropica 31:259-265

McKeen CD, Mountain WB (1960) Synergism between Pratylenchus penetrans (Cobb) and Verticillium alboatrum r. \& b. in eggplant wilt. Can J Bot 38(5):789-794

Meena RS, Kumar S, Datta R, Lal R, Vijayakumar V, Brtnicky M, Sharma MP, Yadav GS, Jhariya MK, Jangir CK, Pathan SI, Dokulilova T, Pecina V, Marfo TD (2020) Impact of agrochemicals on soil microbiota and management: a review. Land 9:34. https://doi.org/10.3390/land9020034

Mizukubo T (1995) Evidence for Pratylenchus coffeae races in differential reproduction on fifteen cultivars (Nematoda: Pratylenchidae). Jpn J Nematol 25(2):85-93

Moens M, Perry RN, Starr JL (2009) Meloidogyne species: a diverse group of novel and important plant parasites. In: Perry RN, Moens M, Starr JL (eds) Root-knot nematodes. CABI Publishing, Wallingford, pp 1-17

Mokbel AA, Alharbi AA (2014) Suppressive effect of some microbial agents on root-knot nematode, Meloidogyne javanica infected eggplant. Austral J Crop Sci 8(10):1428-1434

Noling JW (2019) Nematode Management in Tomatoes, Peppers, and Eggplant. University of Florida publication Series no. ENY-032, USA, p 16 
Noweer EMA, Elkelany US (2019) Biological control of root-knot nematode Meloidogyne incognita infesting eggplant by the nematode-trapping fungus Dactylaria brochopaga and the nematode egg parasitic fungus Verticilium chlamydosporium under field conditions. J Innov Pharm Biol Sci 6(4):1-6

Osman HA, Ameen HH, Mohamed M, El-Mohamedy R, Elkelany US (2018) Field control of Meloidogyne incognita and root rot disease infecting eggplant using nematicide, fertilizers, and microbial agents. Egypt J Biol Pest Cont. https://doi.org/10.1186/s41938-018-0044-1

Papolu PK, Dutta TK, Tyagi N, Urwin PE, Lilley CJ, Rao U (2016) Expression of a cystatin transgene in eggplant provides resistance to root-knot nematode Meloidogyne incognita. Front PI Sci 7:1122. https://doi.org/10.3389/ fpls.2016.01122

Rahman MM, Nahar K, Ali MM, Sultana N, Karim MM, Adhikari UK, Rauf M, Azad MAK (2020) Effect of long-term pesticides and chemical fertilizers application on the microbial community specifically anammox and denitrifying bacteria in rice field soil of Jhenaidah and Kushtia District. Bull Environ Contam Toxicol, Bangladesh. https://doi.org/10.1007/s0012 8-020-02870-5

Robinson AF, Inserra RN, Caswell-Chen EP, Vovlas N, Troccoli A (1997) Rotylenchulus species: Identification, distribution, host ranges and crop plant resistance. Nematropica 27:127-180

Usman A, Siddiqui MA (2012) Effect of some fungal strains for the management of root-knot nematode (Meloidogyne incognita) on eggplant (Solanum melongena). J Agric Tech 8(1):213-218
Di Vito M, Catalano F, Zaccheo G (2002) Reproduction of six population of Pratylenchus spp. from the Mediterranean region on selected plant species. Nematol Medit 30:103-105

Wang K (2019) Reniform nematode (Rotylenchulus reniformis) Linford and Oliveira (Nematoda: Tylenchida: Tylenchoidea: Hoplolaimidea: Rotylenchulinae). University of Florida publication Series no. EENY-210 (IN367), p 4.

Wilson MJ, Jackson TA (2013) Progress in the commercialisation of bionematicides. Biocontrol 58:715-722

Zayed GA, Abdo AA, Hammam HB, Khafagi EY (2017) Cultivation and production of pepper and eggplant in Egypt. Technical issue No. 15, General Administration of Agricultural Culture, Ministry of Agriculture, Egypt.

Zeerak N, labal Z, Kamran M, Iftikhar Y, Arshad M, Abbas H, Javed N, Bashir S, Rehman A (2017) Root knot nematodes associated with eggplant in different localities of District Sargodha-Pakistan and impact of Pasteuria isolates on development of Meloidogyne incognita. Int J Biosci 11(4):107-115

Öçal S, Devran Z (2019) Response of eggplant genotypes to avirulent and virulent populations of Meloidogyne incognita (Kofoid \& White, 1919) Chitwood, 1949 (Tylenchida: Meloidogynidae). Turk Entomol Derg 43(3):287-300

\section{Publisher's Note}

Springer Nature remains neutral with regard to jurisdictional claims in published maps and institutional affiliations.

\section{Submit your manuscript to a SpringerOpen ${ }^{\circ}$ journal and benefit from:}

- Convenient online submission

$\checkmark$ Rigorous peer review

- Open access: articles freely available online

- High visibility within the field

- Retaining the copyright to your article

Submit your next manuscript at $\boldsymbol{\nabla}$ springeropen.com 